\title{
The Role of Orientalists in Presenting "Arabic" to the World
}

\author{
Abeer Obeid Al-Shbail \\ Al-Balqa Applied University, Jordan
}

\begin{abstract}
Almost all Oriental studies agree on the concept that Orientalism is a scholarly research based on survey and comprehensiveness, undertaken by European elites to comprehensively understand the East and to formulate a discursive image of its conditions. It has been agreed that the Orientalist is a researcher who is interested in the deep knowledge of the religions of the East, its cultures, languages, and literatures. It is certain that Orientalist knowledge does not stop at all; it extends as it accumulates to form different and contrastive contexts, and operates according to specific methods. Under our chosen title we intend to show the different various schools of orientalism and their methods of introspection. We also intend to explore the difference between the two concepts of "Orientalism" and "Occidentalism" and the roles they have taken. We will also show how the heritage written in Arabic has been undertaken as the necessary condition for Western institutions to acquire the keys of entering into the East and possessing its grand wealth. It was not possible for the West to succeed in its project had it not began working on possessing Arabic language and the culture in which it is written. That was the first codified step which was seen as the most important factor in learning Arabic and teaching it to future generations of the West, and which perhaps linked the Arabic linguistic lesson with Islam. In this study we will also discuss the most important goals sought by the orientalists as they are doing great services to the West in its discursive progress, as it was strongly shown in their interests in the Holy Quran translations, a phenomenon which is worthy of attention. We studied this matter in comprehensive characterization and analysis. We tried also to find justifications for the Orientalists' interests in modern Arab literary works. Finally, we have reached some notable conclusions in this regard, the most important of which is the mission of the Orientalists. At the same time, we have shown how the Orientalist research has helped spread Arabism outside the geography of the Arab world. Our main goal in all of this is the supplication to Allah the Almighty to extend our nation, language and culture with prosperity and continuity.
\end{abstract}

Keywords: Orientalism, occidentalism, Arabic language

DOI: $10.7176 /$ JLLL/52-10

\section{The Mulch And The Goal}

We have sought in this work to characterize the schools of orientalism and its aims, its methods of direction, and what would have been for us this characterization, unless we found the Oriental history of the emerging thaw that tomorrow the institution of different approaches convergent ends, and perhaps the difference between Oriental thinking and Western thinking in general which pushed Extremists from the West to hostile sites.

One of the differences between the Eastern mind, which is the reason of the Arab mind, and the Western mind represented by the Orientalist mind - as this mind thinks - is that

1. The Arab mind is quick to believe in the things that are not, and it is incapable of building a system of things seen, that is, the natural order governed by fixed laws.

2 - The idea of the nebula is close to the Arab mind, and it is not allowed to discover the systems of the universe and its laws 3. The orientalist mind of the Arab mind - privatized in its language - is accused of abstract historical charges, and it is alleged that its accusation is based on reasoning and reasoning.

\section{In Contrast}

We tried to present to the Arab intellectual elites and face the Orientalist allegations on two fronts: the first is the internal front, which was organized in the Orientalist system, "Mohammed Abed Jabri - Charles Malik" The arena of conflict here that the:

- Arabic as a language of philosophy and strengthens the transfer of natural sciences and contain them, regardless of their accusation of sensuality and inertia.

- Work to differentiate between an Arab mind and an Islamic mind, the first mind of a nation that has become a history, philosophy and science, and the second dimension of Arab Islamic philosophy has ceased to exist since the emergence of the national political mind.

- There are orientalists who have corrected our civilization and our language. They were outside the central European system. They were Louis Massignon, George Cidio and Mar Gilliot, who showed a deep understanding of the Islamic spirit and a division between the East and the Arabs. He also showed respect for the spiritual dimensions of our Arab Islamic world. Work board.

The second is the Arab one, centered on the two selves: heritage and nationalism, and it is counterproductive to the advocates of Orientalism and its magnanimity.

The importance of working in taking the comparative approach, which is the essence of sophistication, and comparison, as we see it, comes out of preconceptions and leads to uncertain results, but approaches certainty.

The importance of research does not close the structure. But keep the structure open to the possibilities of enrichment and dispensation.

3. Search Board

3.1 Orientalism

"A study by a group of Western thinkers on the issues of the East, especially with regard to its history, literature, languages, 
arts, sciences, traditions and customs." 1

In the definition, there are two geographical aspects: the East and the West, the East appears to be the recipient, and the West appears to be the active movement. Orientalism is not only a geographical dimension but a geographical and historical dimension. Serving the strategic objectives of the West and establishing its new world from the Renaissance 1500 to the middle of the twentieth century 1945 after the end of the Second World War, and at this time the West was seeking to acquire the knowledge of the Eastern Nations to be able to have the Kiviyat that enables him to control and acquisition, The French thinker Paul Valery Paul Valery 1871- 1946 "is only seven lambs indigestible group" 2 , and he preached at the Collège de France

Lecollegede France at the founding conference of comparative literature, which symbolizes the West, and the Akbash to the nations of the East.

In the 1312s, when the Synod of Vienna decided to establish a number of chairs for Hebrew, Arabic and Syriac in the institutions of Paris, Oxford, Bologna, Avignon and Salamanca ${ }^{3}$, but for the most part, The interest in the early era of Orientalism was concentrated on the first two oriental languages: the Hebrew language and the relevance of this language to the Christian theology, and the second is Arabic, because of the relevance of this language to the Arab sciences produced by the international culture under the rule of the Abbasid caliphate.

The importance of "Arabic" look in the eyes of orientalists through the number of works written in it, and through the sciences translated into it, and led to a superior type in the Middle Ages, especially in the sciences related to medicine and philosophy, and after the Hebrew and Arabic took the attention of Orientalists extends to Syriac, Persian, And Chinese. Although orientalists were interested in the Oriental languages, their interest in Arabic became more extensive. Translations from Arabic into Latin began in the 17th century and into modern European languages since the second half of the nineteenth century.

With the advancement of Western scientists in the sciences of the East and its geographies, the Oriental lesson is divided into "Far East" and "The Arab Orient".

In the United Kingdom, they have developed the term "orientalist"; in Iran and Turkey they have developed the "specialist"; in Spain and Germany they have developed the "professional", meaning the world or the scholar in a language of the East In particular the "Arab". In Soviet Russia, the orientalism founded by Sergei Ovarov in 1818 was defined by the term "Arabist" and in the literature of Russian scientists, the defender of Arab issues, pro-Arab or admirer ${ }^{4}$.

\subsection{Arabic Is The First Project}

It was clear that interest in the internal world of Arabism emanated from the deep ties of Arabism with the sciences in which it was written, and from its links with the external affairs of the Eastern Nations, Which contributed to the philosophical and experimental production in Arabic from the second century AH until the end of the sixth. Since the beginning of the institutional translations under the patronage of the Abbasid Mamoun (AH) 197 - 218 AH, 813-833 AD, the Greek translation found the basis for his project. He formed a committee of Syrian scientists and entrusted them with the transmission of philosophical and empirical Greek sciences.

Based on previous premises, orientalists realized the importance of Arabic on three levels:

The second level was through the medieval sciences stored in Arabic, and the third was the most important. In their opinion, the rise of the Arabic linguistic lesson was a mediator between the two linguistic systems: the Eastern Persian Indian and West Greek.

On the other hand, the orientalists were working on the disengagement between Greece geographically and the East in an attempt to restore the Greek heritage as the founding base of the mythological and experimental of the European Renaissance in the sixteenth century and beyond. The orientalists had what they claim, The linguistic lesson implicitly science transmitted from Greece as Greece the European miracle in the ancient world, which emerged from without an oriental foothold to establish it.

In the context of the Orientalist interest in the affairs of "Arabic", the Orientalist Weiss wrote that "Arabic is of great importance to those who wanted the Islamic civilization, and its importance goes beyond its active and great role in the history of the linguistic lesson in general, to an effective functional act in the history of human thought at all" 5 .

Wais's former view of the orientalist confession of the Orientalists in Arabic and the science of its codification shows that it is the basis for Orientalist research in reading the Islamic codes and the Eastern heritage in its entirety. Wise's confessions come in a context contrary to the central Western tendency that claims that the Eastern influences did not contribute to European Renaissance, a miracle from Greece and Romans to the sixteenth century and results, the European Renaissance methodology is the only way to progress, and this road self-creation. "Aryan race with multiple ethnicities monopolized a special typology not enjoyed by others, Which can be explained only by their return to fixed ethnic characteristics ${ }^{6}$.

3.3 But how did this western superiority emerge?

Since the beginning of the sixteenth century, the economic factor dominated the European political philosophy, it is known that European geography is not rich in resources, and hence the political thinkers on ways to own the wealth of the East, and had to be an ideological cover of Western intentions, intellectuals and orientalists sought the justification of the past The

\footnotetext{
${ }^{1}$ Literary Dictionary - Sabour Abdel Nour - Dar Al-Ilm for millions - 1979.

${ }^{2}$ Quoting the book of comparative literature of Muhammad Ghimi Hilal - Nahdha - Egypt for printing - I 9. Chapter I.

${ }^{3}$ Edward Said - Orientalism - Translation Kamal Abu Deeb - Arab Research Foundation edi.11,p. 80

${ }^{4}$ Bernard Lewis - The Issue of Orientalism - Translation by Hashim Saleh - Former Source - p. 91.

${ }^{5}$ We took the witness from the book "orientalists and their theories in the origin of linguistic studies - 1992 - Dar Haneen - Amman

${ }^{6}$ Martin Bernal - African - Asian Roots of Ancient Civilization - Cairo Journa
} 
present, from the past, used the two imperial empires: Greek and Roman, and from the present they cherished their achievements, especially the geographical and canonical reforms, and then used the philosophers of the 17th century and 18 th century Enlightenment philosophers, Moukratih as an achievement "exceeded" human history ancient and modern.

The phenomenon of colonialism is justified by the Western centralism. The whole world is in the dark and in the darkness of the white man's feet. Hence, the great writers have borrowed the other place in the great works of literature. Robinson's story of Daniel Defoe 1660-1731 which was written by 1719, bears witness to this metaphor. The political leaders of the West did not integrate with the peoples of the colonies. They worked to increase the differences. They produced two illogical and non-historical visions: the first is self; this is based on exceptional and complete; Extinction, arrogance and satanism.

These two perceptions produced by the central Western market some orientalists, and some of the expatriates of the Arabs, but many of the Arab thinkers have encountered these perceptions of the West, the thinker Hasan Marwa opinion in the trend of humanity contrary. "The claim to talk about the competence of a people of mental or humanism without other peoples is not a historical one. The two races are a common form of awareness among human races, and he heritage of a people or present is not without these two trends, but one that determines the superiority of one of them over another is not the characteristics of race. It is the decisive historical circumstance ${ }^{1}$. "The English scientist Gérard Huxley reinforced racialism:" Nature has given human races equal opportunities for development, But the Anglo-Saxon race was the most responsive to the development of the genetic characteristics that distinguish it from others and prepare for the launch of experimentation and progress ... " 2 .

The modern Arab thinkers have rejected the Orientalist claims, especially concerning the Arabic language and its sciences. In this, a member of the Arabic Language Academy in Damascus says: "We understand why the colonizers took among the methods of combating the Arab and Islamic nation an attempt to destroy the Arabic language and why they failed to impose their languages during their occupation of the Arab homeland and they described our Arabic language as backward and not keeping pace with the spirit of the times" ${ }^{3}$

The reaction of Arab intellectuals seems to be closer to the tribal act, placing orientalists and thinkers of the West in one structure, and forgetting that there are Orientalists and Arabists who support Arabs and Arabs and their causes. We mention of them the English Margolisuth 1858-1990. The presence of poetry before Islam is only recognized by the Holy Quran, because it is found that the Koran is a source of knowledge of poetry, and this indicates that the so-called ignorant is made in the Umayyad period, and recall the Russian Gregory Sharbatov, who developed the Russian-Arabic dictionary, and founded a special section of Arabic dialects in Russian Orientalism, And before him Ka Agnatio Sgrachkoviski 1883- 951, who wrote about the geography of the Arab countries and about the contributions of the Arabs to the intellectual renaissance of Renaissance Europe. We mention the French philosopher Blacherc 1900-73, who wrote about the history of Arabic literature fairly and admirably. He also studied the German language, Karl- 1956, which wrote the history of Arabic literature with care and perfection without prejudice and then wrote "History of the Islamic peoples" and recall the German orientalist Ziegridhonka, author of the book "Sun of the Arabs shining on the West," a work that deals with the history of the Arabs and the effects of Arab civilization and Arab scholars in the Middle Ages on the And the Orientalists who encouraged to learn Arabic in the western corridors, and drew attention to the importance of William Badwell 1561-1632 in the early era Of Orientalism, and his call was a founding step for the spread of the Arabic language on two levels: the first is the formal institutional level, the second is the educational level in the monasteries and the schools. It is natural that his call is not devoid of non-scientific goals. He says of the Arabic language: "It is the only language of religion, Work, Starting with Algeria happy to the country of China" 4 .

\subsection{Business Relations And Scientific Institutions}

It is important to mention the importance of trade as a factor in the spread of Islam in the Far East, "Indonesia, Malaysia, Singapore, China, India," especially through Yemen's merchants, the people of Yemen with trade and a long tradition stretching to the cities of Saba, Mein and Hamir on the Indian Ocean. The spirit of commercial adventure is effective in the imagination of Yemen until they transferred Islam to the Far East - from Indonesia to China - With the European Renaissance and the technical and industrial progress and the need of the countries of Europe to expand outside its geographicalities, The West consumes resources and returns them with goods that impose themselves within the context of need.

The British East India Company (1600-1855) pioneered the establishment of Hailebury College for the teaching of Arabic language for engineers and technical workers so that they could get organized in the space in which the company operates. Of course, the trainees did not learn Arabic only to suit their career status.

The sons of Arabia today learn English, to organize themselves in the oil labor market, which is part of the global capitalist system.

The other company was the French East India Company (1664-1769). It had two main purposes: the competition of the British company in India; the second was the completion of the colonial empire of France; the labor force attracted both French and Arabic workers, which enabled workers to respond to the necessities of production.

And then followed the companies called colonial companies, which resulted from the colonialism of Western European countries, especially England during the sixteenth and seventeenth century, the most important company Gulf Hudson, and was organized by the English court of 1668 for trade with the Indians, and this contributed to the control of Britain to the region, Contributed in 1821 British monopoly of international trade, and the breadth imposed on the workers and employees and experts of all nationalities, and the use of languages of nationalities imposed on the level of deliberation on the

\footnotetext{
${ }^{1}$ Material tendencies in the Arab-Islamic philosophy - Dar Al-Farabi - 1978 p116 - Beirut.

${ }^{2}$ Experimental Method - History and Future - Translated by Hamed Taher - Anglo-Egyptian Library - Cairo - 1990 - Introduction Translator.

${ }^{3}$ Arabic Language and Challenges of the Age - The Syrian Book Organization - Damascus 2002 - p 114.

${ }^{4}$ Orientalists and their theories in the emergence of linguistic studies - a previous source - p. 22
} 
company's system.

Italy is the first country to establish trade relations with the Middle East, especially the Arab Mashreq. This has led the traders to acquire the level of communication from the Arab world, and the Venetian people are usually interested in foreign languages that benefit them in trade. Arabic was Arabic, and Arabic continued to exist in Venice until the fall of Constantinople in the hands of the Ottomans 1453, after which the commercial and cultural ties between the Arabs and the Italians were cut off. 1

It is worth mentioning the presence of a group of French thinkers and some orientalists to Egypt during the Napoleonic campaign of 1798, within a comprehensive vision of Napoleon and the colonial project of France in Egypt and the region to promote the acquisition of the geography of Egypt by acquiring its cultural face, including Arabic.

In the United Kingdom, the Oxford University founded the Arabic Language Chair in the 12th century. Archbishop Lud Loud1636, with the aim of establishing the Arabic Chair, "comparing Biblical texts with Quranic verses," claimed that any comparison would necessarily lead to a belief in superiority Biblical texts that in turn lead to Christian extension.

At the College de franc, College of French Research, the Chair of Arabic Language 1581 was created by Geum Postel, explaining his decision: "It serves as a universal language in dealing with Moroccans, Egyptians, Persians, Turks, Tatars and Indians. It also contains Thar literature, He could challenge all the numbers of the Christian faith by the sword of the Bible ${ }^{2}$. "This statement from the Postel exposes the pretense of orientalism.

3.5 Holy Quran ... Dominant Space

The Holy Quran was first translated into Latin in 1143 by a decree by Petros Venizabillis, the head of the Clooney monastery in Spain. In Italy, attention began to be given to Arabic from the Gospels through printing. Cardinal Frederick de Merses created a printing press that completed 18,000 copies of the Bible in Arabic, And issued an appendix in each copy put some of the basic rules simplified and basic, in a book called "rules of Arabia" 3.

The orientalists - with this double translation - achieve two goals: the first is the satisfaction of science should not be denied, or not put it in the strategies of the East-West, And the second is the establishment of the manifestations of colonialism and Christianity later.

The early orientalists recognized the importance of "Arabic" as a historical act that began with the seventh century AD until it reached the twelfth century in Andalusia, where the Arab Islamic philosophy matured and revealed itself through Ibn Rushd 1126-1198 AD. It was also experienced or slightly advanced by a group of philosophers Kalahati and Ibn The Orientalists realized that the Arab scientific project of the Caliphate State began from translation as a project for the Abbasid Mamoun and balanced between the Arabic and the Persian Gnosticism on the one hand, and the Greek language on the other. Thus, the Baghdadi arena became the cultural arena of multiculturalism. And the ethnic under the condition of the Islamic caliphate. ${ }^{4}$

The orientalists did not find that in the translation of the Holy Quran into Latin as a first step, and in the national languages later on, it was possible to enable the grammatical structures of Arabic, which would help them in another project, namely the dismantling of the Old Testament in Hebrew and the New Testament in Aramaic. Includes a set of signals, rattles and riddles that can only be decoded with the knowledge of Arabic, and in particular that all the effects coming from those two covenants have eroded, and seemed not prepared to continue, hence they found in the "Arab" safe haven for the credibility of the texts of the two covenants.

In the 19th century, translations of the Holy Qur'an were translated into Russian by Sablooukof Siblukov (1878) and the translation of the Uzbek Soviet Muhammad Nuri Ottoman in the last quarter of the twentieth century. It was translated three times, each time it was developed in its own language. And he did not want to translate it completely. Rather, he wanted to select some verses as special texts in the law, which would enable them to repent of the total.

The translation of the French by Jean-Berk from 1910 to 1955 was published in different geographical regions, and it lasted for sixteen years. It was adopted by Albin Michel in 2002. It is noteworthy that the translator Berk is a member of the Language Complex Arabic in Cairo.

A recent translation of the Holy Quran translated by the French d. Masson, entitled "Meanings of the Quran," is an easy and accurate translation, and therefore easily spread. Since its publication from the Galimard House in 1967, it has taken the interest of French commentary.

Bibliothequedepleiade It is remarkable that the translator resorted to the title of "meanings of the Koran" to get rid of the burden of style, and save the translation of the rhetorical observation that may be shown by others who mastered Arabic.

The interpretation of the Quran leads to the enrichment of the canonical space in Arabic and in the Islamic legal sciences. This allows the Church's men to argue with the Arabs and with the non-Arab Muslims so that the Quran can be translated into Arabic. They have, according to them, persuaded Muslim communities to break away from Islam and convert to Christianity. This is not a new claim. Ever since Peter's revered decree 1143 translated the Koran for the first time, he stated that "the purpose of the translation is to confront the adversaries - Arabs - Muslims - This is required to know the opinion of the opponent first, and this can only be done by translating the Quran ${ }^{5}$. "The words of Peter the Apostle are not individual words, but the disclosure of

A project that is growing and progressing in phases, but at the same time recognized the importance of Arabic science -

\footnotetext{
${ }^{1}$ Considered in the Egyptian Encyclopaedia Encyclopaedia - C21080-1081 - Cairo 1986

${ }^{2}$ Looks at Orientalism Movement - House of Culture - Cairo 1990-54-55 to Abdel Hamid Madkour

${ }^{3}$ Orientalism is the face of intellectual colonialism - Abdel-Matal Mohammed Al-Jabri - Library Wahbi - Cairo 1995 - p. 81.

${ }^{4}$ Dr. Mukhtar Fajari - The Arab-Islamic Thought From Ta'ilia to Meaning to the Interpretation of Understanding - The World of Books - Irbid

- Jordan - 2009 - p. 253

5 Johann Fock - History of Orientalism - Arab and Islamic Studies in Europe - 20th Century - Translation by Omar Lutfi Al-Alam - Dar Qutaiba - Damascus 1996 - pp. 14-15
} 
language - Sharia - and also recognized the importance of science transferred to the Arabic language and the need of the West ecclesiastical..

3.6 Orientalism and Arabic literary Works

Since 1945 and shortly after the end of World War II, the German nation is rebuilding itself on more than one level. At the scientific level, institutions are restoring their role in Germany and Europe. On the economic level, the industry is active and competing with the victories. And it is thus convincing that the German orientalism is interested in the Bible and its manifestations in the living languages, including Arabic, and it seems that the German Protestant doctrine was associated with the national state project, Restoration of the industrial project of the German bourgeoisie, who 1939- 1945 war, destroying it.

Modern orientalist interest in modern Arabic literature came after the traditional Orientalism of ancient Arab creations, "poetry, codes, works, language sciences, philosophies, eloquence,". It is remarkable that the miraculous face that characterized the East in the eyes of the West The Orientalist interest in the Arabic novel was not only because it was a literary genre, but because, as it relates, it stored the social, political and cultural problems of the peoples of the Middle East and North Africa.

One of the first tasks of the new orientalism was to work on separating the Arab issues of interest to the Arabs alone and between the issues of the Middle East, which includes the peoples of Iran, Turkey, the Arabs and others. Therefore, the "image" of the Arab personality in the work of the Arabists and orientalists has been rid of the remnants of the Middle Ages In the imagination of the people of the West, he reinforced the story of "A Thousand and One Nights."

The image of the Arab today in Western literature is a new picture formed by the novel, the story, the short story, and the narrative texts translated into European literature, especially German literature. Contemporary Arab man became a vocabulary of the modern world, not one of the Ottoman Empire, Previous.

Hence, the new orientalist research began to form a group of opinions on a single axis, written by a group of researchers. In this way, orientalism moves from individual efforts to institutional efforts and eliminates individualism.

The Orientalist Rotund Wildland wrote in the Modern Western Literature 1980, and then the German orientalist Shevan Field wrote about the biography of the Syrian poet Nizar Qabbani ${ }^{~}$. The interest in modern literary works is no longer confined to Germany, but rather to Switzerland as a major step in the interest of Arab institutions in Arabic literature, And it seems that the translation options were the achievements of young writers in the Arab countries, and the interest of young people not for their artistic ethics, but an attempt to read the emerging Arab societies from the inside, an introspective reading, She founded the publishing house of 1983, Linus House. The orientalist, Hartammot Vindrich, founded the German publishing house Dara, which translates into Arabic. She translated into German as one of the predominant languages in Switzerland ${ }^{2}$. It is possible to explain these translations to Swiss German as a striking phenomenon The Western world is no longer a single bloc. Rather, it is the state of its project, which imposes on its users and orientalists a way of strategic thinking of the East-West relationship, and by adopting a special approach to each. From the orientalist and orientalist.

German and Swiss orientalism is turning to the Arab Mashreq, Iraq, Syria, Palestine and Egypt. These countries are experiencing crises and issues that are closely related to the interests of the European Union. They have therefore translated some works by Taha Hussein, Sayed Qutb, , Salah Abdul Sabour, as a founding step and then translated into the new generation as the manufacture of God Ibrahim and Ala Aswani,... And from Iraq translated poets of modernity Nazik angels, Abdul Wahab al-Bayati and Badr Shaker al-Sayab, and after them, Sarkon Bolus and Saadi Yusuf, and from Palestine translated poets The Palestinian issue: Mahmoud Darwish, Moin Bisiso, Im And from the Arab countries of North Africa translated Tahir Wattar and Wassini Alaraj from Algeria, and the book of the Moroccans was most of their work moved from French to European languages without going through Arabic ${ }^{3}$.

The orientalist Friedrich Rückert also translated the Arabic heritage works in which he found something to enrich him, or the Western reader sings about many of the works of heritage. In order to translate the work of prose, With poetry,

The source of the translation into German is the introduction of the German and Swiss readers and those who read in German the methodology of medieval and modern Arabic authors.

\subsection{Surprise and Reverse Orientalism}

It was called the Arab intellectuals who agreed with the Oriental orientalists who refuse to have the Arabs past or present - an Arab Islamic philosophy, but the science of Greece is transferred to Arabic ${ }^{4}$, And the Arabs did not have a little philosophical action, and the thinker Tizini refers to some names such as the Moroccan writer Mohamed Abed al-Jabri, to Charles Malik of Lebanon, and Mohammed Arkoun of Algeria, and it seems that the situation represented by the Jabri thinker is not limited to production in one field knowledge, Cash judgment The component of the mind to the three is the graphic component and the spirit of measurement, and the component of the prophylactic coming from Greece, and the component of the Eranic coming from the East, and describes him as the historical enemy of the Greek proof, and sought to determine these structural constants of the Arab mind, He sought to achieve something else. He found out that the Arab mind lives on the margins of history when it is oppressed by the "sacred" and denies the scientific methods. The rationalism, the feminization and the excavations are all absent from the Arab-Islamic mind. ${ }^{5}$ "Orientalism in its western origin and its persistence - in general - an expression of the interests of Western colonialism towards the countries of the" East "could not but proceed from the dominant position of Western colonial thought, which is based on the belief that the countries of the

\footnotetext{
${ }^{1}$ Looking at text migration - Studies in cultural exchange - Dr. Abdo Abboud - Damascus - Union of Arab Writers - 1995

${ }^{2}$ For further consideration d. Mousa Rababa'a - Yarmouk University - Conference of the Faculty of Arts First 2007 - World Books - p. 416

3 Source: p. 417.

${ }^{4}$ The book was published by Al Wathba House Homs and Dar Al Majd Damascus - Syria - 1996

${ }^{5}$ Structure of the Arab mind - a previous source - i - p. 446 and beyond
} 
East and the West The European character of the mental civilization, and the other nations margins and parties .. " 1

Tizini, as taking the materialistic dialectical method, declares that Arab-Islamic philosophy is an authentic philosophy in Arabic and at a long historical stage. It passed through the translation phase at the beginning of the ninth century AD and continued to rise and rise until the end of the twelfth century. A single book criticizing the writings of Muhammad Abed alJabri, the structure of the Arab mind - the formation of the Arab mind - the political Arab mind - the Arab moral mind - the contemporary political discourse - says: "Yes Jabri starts in his writings from the European Orientalism "

Central European ", which we find one of the great foundations in the term" mentality "and the duplicitous between Western European mentality and oriental mentality is not Western, and this would doubt that Al-Jabri produces a consistent text in the sense of" 2

Al-Jabri describes the Arabic language as having two characteristics: not its sensory history; it is a non-historical language; history is not responsive to the requirements of evolution; and if the stereotypes that Hebron and its colleagues put into Arabic give it a kind of internal dynamic, It has worked to "immunize" of each change and evolution proposed by history on them, so did not evolve and did not change and could not be self-generated. ${ }^{3}$

If the thought of the Jabri thinker has some truth to die Arabic since the second century AH, has forgotten the thinker mentioned that - a factor in the field of philosophy - how the Arab buildings could promote the study Almtazili and establish the most philosophy in the Middle Ages, the Arab Islamic philosophy, and then ask him In what language did Al-Farabi, Ibn Sina, Ibn Jubayr, Ibn Tufail and Ibn Rushd write? If the Arabic did not develop itself and has the ability to become rich from others, it could not be the language of interpretation and translation.

In contrast, the Russian Arabist Anas Khalidov sees that the Arabic language has the ability to give a sufficient number of words and grammatical structures to convey similar ideas and knowledge that were strange. The translations were carried out with a minimum of words borrowed from others. The Arabic language repertoire found ways to present the ideas of intelligent writers in logic The dialectics of ancient Greece, Byzantium, Sasanian Iran and distant India, as well as the dogmatic discussions of Christians, Maronites, Sabean, Freemasons, Zoroastrians, and Quraqs. He expressed Euclid's geometry and the richness of the minutes of philosophical trials, "All of this is expressed in Arabic," he said. "The Russianspeaking Russian is closer to the Arabic ${ }^{4}$ language and the spirit of one of its sons, who are as close to it as al-Jabri.

The term Orientalism inverted is a work of the Syrian thinker d. Sadeq Jalal Al Azm, created by his reading of Edward Said's book "Orientalism Knowledge - Power - Creation" published in the United States of America 1982 and translated into Syrian Academic Arabic d. Kamal Abu Deeb 1981, published by the Arab Research Foundation in Beirut, the book was published in English, translated in two years into French, German and Italian, but the thinker Sadiq Al-Azm wanted to say: "The holistic picture

Which cultural Orientalism has built on the East, involves fundamentally racist attitudes from the East, partial interpretations of its reality, inhumane assessment of its people and societies, and the effects of material interests stemming from the benefits of its subjugation and exploitation - after its study and its process - Can be the result of the application of any scientific approach neutral in the knowledge of the East, or any study that truly reflects the objectivity and intellectual independence and renewed desire to seek the truth for the subject to study and scrutiny " 5

The reading of Edward Said's "Orientalist" book of thought reinforced Sayid's point of view - he writes from within the Western world - and established Arab reactions to the negative aspect of Orientalism. Despite the implicit aims of this phenomenon, Orientalism, it enriches the East- , The discipline between nations not only in the positive phenomena, but at all levels, and remains the knowledge arena ready for constant debate between the inside and outside.

The Egyptian Surrealist, Anwar Abdel Malik, founded the reverse orientalism since 1963 when he wrote under the title "Orientalism is stymied." The Orientalists are oriental, central European, and do not care enough about the Afro-Asian scientists, their methods and their successes, they are obsessed with the past, Contemporary of the Eastern peoples "6, and did not hesitate to call for the trial of orientalists.

However, Orientalism and orientalists were a phenomenon of modern science, regardless of their origins and affiliations with Euro-American projects and the global capitalist system. This phenomenon contributed to the movement of the inhabitant and bitterness in the Arab culture and created the Arab elites for scientific debate and mutual dialogue with orientalists. Of the unequal relationship between the center and the parties..

\section{Summary And Results}

1- Orientalism is a phenomenon that originated in 1312 as a project that exposes the first phase of the European Renaissance, which lasted until the year 1500. This year, we mean two global projects: the ecclesiastical reform and the geographical statements, and orientalism in this phase focused on Western Christian and Arab Islamic conflict. Conflict as the key to all Eastern sciences.

The second phase of orientalism was directed towards other knowledge spaces, such as the economies of developing countries, and the different creeds of the peoples of the East, especially India, Iran and Turkey.

3 - The appearance of oriental orientalism stirred up a scientific movement in all the languages of the world, including Arabic, and the reaction of Sadiq al-Azm was important because it was transferred to these languages, and Claude Cohen and Maxim Rodensonubernar Lewis and Alan Rossion and Francisco Gabrielle responded to Edward Said in their different

\footnotetext{
${ }^{1}$ In the current intellectual debate on the theory of heritage - the new Thought House - 1989 - PO Box 113 - Beirut

${ }^{2}$ From Western Orientalism to Arab Surprise - a former source - p. 97

${ }^{3}$ The formation of the Arab mind - Center for Arab Unity Studies - 4 - 1989 - Beirut p. 86.

${ }^{4}$ An article by the author entitled "Arabic language" published in articles in Arabic culture between the fifth and fifteenth centuries AD Institute of Orientalism - St. Peter Borg

${ }^{5}$ Orientalism and Orientalism inverted - Dar al-Haditha - Beirut 1981 p. 7

${ }^{6}$ Orientalism among his supporters and opponents - Hashim Saleh - Dar al-Saqi - 2000 - p. 166
} 
languages, Moved to Arabic.

4- The conflict between the Arab elites and Orientalist symbols can only be classified within the strained relations between the East and the West. Arabs either express the Islamic trend or the nationalist trend. Orientalists express the interests and privileges of the capitalist West.

5. Not all Western elites, not all orientalists, are in one direction. Despite their agreement on the need to adopt the historical scientific methodology and their call to apply it to the Arabic language and heritage and the Islamic texts, they are different. Marxism tends to the Marxist trend, while Bernard Lewis adopts the philological methodology Which does not deal with the socio-economic conditionality of the studied subject. Rather, it examines ideas as an independent entity. Claude Cohen tends to the economic and social aspects.

6 - Orientalism is an organic part of Western civilization, and has formed a system of knowledge and other methodology, both - regardless of the extremism of some orientalists negatively - contributed to the Arab-West culture.

7. Not all Arab elites are anti-Orientalist, and not all are familiar with the methodological, epistemological revolution that took place in the West in the last third of the twentieth century. This has delayed the emergence of an Arab intellectual system that establishes the knowledge revolution.

\section{References}

1. Arai, T., Aiyama, Y., Sugi, M. \& Ota, J. (2001), "Holonic Assembly System with Plug and Produce", Orientalism and Reversed Orientalism - Dr.. Sadeq Jalal Al Athem - Dar Al Haditha - Beirut - 1981

2. Orientalism - Knowledge, Power, Creation - Edward Said Translated by Kamal Abu Deeb - Arab Research Foundation 1981.

3. Orientalism between the Callers and Opponents - Dr. Hashem Saleh - Dar Al-Saki - London 2000.

4. Orientalism in the Horizon of Blockage - Dr. Salem Hamish - National Council for Culture - Rabat 1991.

5. Orientalism and Alienation of the Arab Historical mind - Dr. Mahmoud Yassin Oreibi - National Council for Culture Rabat 1991

6. Towards a Theory of Culture - Criticism of European Concentration and Reverse Concentration - Dr. Samir Amin Institute of Arab Development 1989.

7. Arab Intellectuals and Heritage - George Tarabishi - Riyadh Al Rayes Publications 1991 London.

8. The End of History and the Last Man - Francis Foucault Yama - Center for National Development - Translation of a team under the supervision of Safadi's plan.

9. The History of Arab-Islamic Thought - Mohammed Arkoun - The Arab Cultural Center - Rabat 1996

10. Central Western - Dr. Abdullah Ibrahim - Arab Cultural Center - Rabat 1997.

11. Islamic Centralism - Dr. Abdullah Ibrahim - Arab Cultural Center - Rabat 2001.

12. Post-Central European - Peter Gran - Translation of Atif Ahmed - Ibrahim Fathi - Mahmoud Majid - Supervision Rauf Abbas - Supreme Council of Culture - Cairo 1998.

13. Arab Islamic thought from the interpretation of the meanings to the interpretation of understanding - d. Mokhtar Fajari World of Books - Irbid - Jordan - 2009.

14. Discovery of European Progress - Dr. Khaled Ziadeh, Dar Al-Tali'ah, Beirut, 1981.

15. Structuralism and its Implications in Contemporary Arab Thought, Ibrahim Mahmoud, Dar Al-Alenab, Damascus, 1994.

16. Open Letter to European intellectuals - Dr. Mohammed Saleh Al-Harmasi - Union of Arab Writers - Damascus - 2011.

17. What Islam promises - Roger Garaudy - Dar Al Wathba - Damascus - Translated by Qusay Atassi 1983. 